\title{
Spinal Cord Injured Women, Pregnancy and Delivery
}

\author{
W. H. Verduyn, M.D. \\ Medical Director, Midwest Rehabilitation Institute, Covenant Medical Center- \\ Schoitz, Kimball and Ridgeway, Waterloo, Iowa 50702, U.S.A.
}

\section{Summary}

The author presents a review of his personal experience, a patient survey and literature review on 33 spinal cord injured women, who had a total of 50 deliveries.

Key words: Spinal cord injury; Autonomic hyperreflexia; Pregnancy; Delivery.

\section{Introduction}

The author's interest in pregnancy and delivery of spinal cord injured women was sparked by his involvement with two of the spinal cord injured women on the unit. As a result of the lack of significant information in the literature, an effort was made to collect a larger number of pregnancies and deliveries. The collected information was classified in different groupings in order to deal with a number of important issues related to the spinal cord injury.

\section{Case Reports}

With the improvement of acute care and effective rehabilitation, pregnancy and delivery of spinal cord injured women will occur more frequently. Our staff from the spinal cord injury rehabilitation unit felt fortunate when we had two tetraplegic patients who were pregnant. Staff members were involved in prenatal care, were present during delivery and were involved with postnatal care. Potential problems were identified as

(1) Early labour

(2) Hyperreflexia

(3) Urinary tract infection

(4) Spinal cord injury care

Active early labour was stopped effectively with Terbutaline. Hyperreflexia was controlled with Amyl Nitrate, Arfonad if needed, and if the hyperreflexia was uncontrollable, a Caesarian section(C-section) would be performed with epidural anaesthesia. Urinary tract infection was treated with long term antibiotics such as Ampicillin or Keflex, and related yeast vaginitis was treated with Mycostatin. 
Table 133 women (20 patient survey, 13 literature review)

\begin{tabular}{lr}
\hline T6 and above & 21 \\
Below T6 & 12 \\
\hline Total of 50 deliveries (1 intrauterine death, 2 sets of twins).
\end{tabular}

Table 2 Causes of paralysis

\begin{tabular}{lr}
\hline Arachnoiditis & 1 \\
Car Accident (Tabash et al., 1982; & 15 \\
$\quad$ Nath et al., 1979) & 1 \\
Motorcycle Accident & 2 \\
Horse Accident (Oppenheimer, 1971) & 1 \\
Tumour and Surgery & 1 \\
Scoliosis Surgery (Dickinson, 1977) & 2 \\
Transverse Myelitis & 1 \\
Gunshot (Ravindran et al., 1981) & 4 \\
Unknown Trauma & 1 \\
Baseball Bat & 1 \\
Rock Slide & 1 \\
Aeroplane Crash & 1 \\
Fall off Garage Roof & 1 \\
Cord Hematoma &
\end{tabular}

Table 3 Four women were pregnant at the time their paralysis developed

\begin{tabular}{lll}
\hline Tumour and Surgery & 22 weeks & Normal baby \\
Car Accident & 14 weeks & Normal baby \\
Car Accident & 21 weeks & Normal baby \\
Gunshot (Ravindran et al., 1981) & 14 weeks & (Intrauterine death, induced at 20 weeks) \\
\hline
\end{tabular}

Table 4 Level of spinal cord lesion

T6 and above: 21 women-27 deliveries (1 intrauterine death, 1 set of twins).

13 vaginal and forceps

7 vaginal ( 1 breech)

7 C-sections (Nath et al., 1979)

During 22 of these deliveries, hyperreflexia was experienced. (1 patient developed a cerebral intraventricular bleed with coma.) (Oppenheimer, 1971; Tabsh et al., 1982; Ravindran et al., 1981; Nath et al., 1979)

Below T6: 12 women-23 deliveries (1 set of twins).

3 vaginal and forceps

8 vaginal

$12 \mathrm{C}$-sections ( 1 patient $4 ; 1$ patient $2 ; 5$ patients 1 )

(1 set of twins)

\section{Indication:}

1 fear of bladder damage

1 ruptured membranes

1 premature twins with presenting cord.

Table 5 Physicians managing pregnancy and delivery

Spinal Cord Injury (S.C.I.) Specialist 2

Obstetrician 38

Family Practice/General Practice 4

Family Practice plus Obstetrician 1

Obstetrician plus S.C.I. Specialist 4

Father 1 
Table 6 Problems related to pregnancy and delivery

\begin{tabular}{lll}
\hline Pedal Edema & 1 & \\
$\begin{array}{l}\text { Increased Seizures } \\
\text { Overweight with Difficulty of }\end{array}$ & 1 & \\
$\quad$ Transfer & 3 & Patients in 6 pregnancies \\
Thrombophlebitis & 1 & Treated with Heparin \\
$\begin{array}{l}\text { Premature Labour 7 weeks, Treated } \\
\quad \text { with Bedrest/Terbutaline }\end{array}$ & 1 & Delivery at 39 weeks \\
Premature Labour 6 weeks, Treated & 1 & Delivery after induction at 35 weeks \\
$\quad$ with Bedrest/Isoxsuprine & & \\
Premature Labour 8 weeks, Twins, & 1 & C-section \\
$\quad$ Presenting Cord & $8^{\star}$ & \\
Urinary Tract Infections & & \\
$\quad$ Tabsh $e t$ al., 1982; Young et al., 1983) & 2 & \\
Pyelonephritis & 1 & \\
T.I.A. Like Episodes & 1 & \\
'Sick all the time' & 4 & \\
Anaemia & 5 & \\
Decubitus Ulcers &
\end{tabular}

* Although patients reported taking antibiotics during an additional 14 pregnancies for bladder infection.

Table 7 Treatment of hyperreflexia

\begin{tabular}{|c|c|c|}
\hline \\
\hline \multicolumn{3}{|l|}{$\begin{array}{l}\text { Epidural (Tabsh et al., 1982; } \\
\text { Nath et al., 1979) }\end{array}$} \\
\hline Anaesthesia & 1 & $\begin{array}{l}\text { (Patient reported physician stated she had } \\
\text { hypertension.) }\end{array}$ \\
\hline 5 C-sections ( 3 in C5-6 Tetraplegics, & & \\
\hline 2 in C6 Tetraplegics) & 2 & \\
\hline Amyl Nitrate & 1 & \\
\hline Ditropan Triple Anaesthesia, & & \\
\hline Guanethidine & 1 & \\
\hline Arfonad & 1 & \\
\hline Sodium Nitroprusside & 1 & \\
\hline Magnesium Sulphate and Demerol & 1 & (Physician diagnosed pre-eclampsia) \\
\hline Apresoline & 1 & $\begin{array}{l}\text { (Only one dose after patient went into } \\
\text { coma) }\end{array}$ \\
\hline $\begin{array}{l}\text { Diazepam plus Diphenhydramine } \\
\text { (Young et al., 1983) }\end{array}$ & 2 & \\
\hline $\begin{array}{l}\text { Hydralazine plus Diphenhydramine } \\
\text { (Young et al., 1983) }\end{array}$ & 1 & \\
\hline $\begin{array}{l}\text { Hydralizine plus Diphenhydramine } \\
\text { and Promethazine (Young et al., } \\
\text { 1983) }\end{array}$ & 1 & \\
\hline
\end{tabular}

A case study was written on both of the pregnant women. Case number 1 was a C5-C6 tetraplegic who delivered a 2339 grams baby girl with an Apgar score of 9-10. Case number 2 was a C2-C7 subtotal resection ependymoma tetraplegic (incomplete) who delivered a 2637 grams baby girl with a Apgar score of 8-10. Both babies were considered mature, with a gestational age of 38 weeks. Both babies were delivered with outlet forceps and did not need episiotomy. Babies were kept in reverse isolation in the Newborn Nursery. Mothers went back to the Spinal Cord Injury Unit after a few hours observation in the Delivery Room. A mail survey and literature review continues. So far, 33 spinal cord injured women were identified who delivered a total of 50 babies ( 2 sets of twins and 1 intrauterine death). In 22 of the 27 deliveries in women with injuries at T-6 level and above, hyperreflexia occurred (Rossier et al., 1969, 1970) (7 C-sections, 
1 after hyperreflexia developed). Twelve women were below T-6 and delivered 23 babies ( $12 \mathrm{C}$-sections).

\section{Patient Survey and Literature Review}

The separation of patients with a neurological level of T 6 and above, from those with a level below T6 was primarily to separate out the women that were likely to have hyperreflexia. Of the 27 deliveries in the category of T6 and above, 22 had hyperreflexia. Seven had Caesarian sections (one patient reported hyperreflexia as indication for Caesarean section).

Of the total of 50 deliveries, there were $19 \mathrm{C}$-sections, certainly a high incidence. These were in 11 patients, 1 patient had $4 \mathrm{C}$-sections, 1 had $3 \mathrm{C}$-sections, 3 patients had $2 \mathrm{C}$-sections and 6 patients each had 1 . The indications given were: hyperreflexia, ruptured membranes, fear of bladder damage. The incidence of the use of forceps is 15, which is fairly high. There was 1 breech delivery.

Prematurity: There were only 4, one at 5 weeks, two at $6 \frac{1}{2}$ weeks and a pair of twins at 8 weeks. One was treated with Terbutaline successfully and delivered on her due date. Another was treated with Isoxuprine for 1 week and induced 5 weeks early. One, pair of twins, was born at 8 weeks, post C-section, because of presenting cord. There were some deliveries from 2 to 4 weeks prior to the expected due dates but not really premature. Post maturity did not appear to be a real problem. The time varied from $1 \frac{1}{2}$ weeks to 4 weeks.

With regard to birth control, pills were used by 9 women, either alone or in combination with IUD, condom, and foam. The rhythm method was used by one patient, who had 5 pregnancies.

One woman had artificial insemination.

Table 8 Age of Injury

\begin{tabular}{ccc}
\hline Age & Number & \\
\hline 5 & 1 & \\
9 & 1 & \\
12 & 4 & \\
14 & 1 & 11 \\
15 & 2 & \\
16 & 2 & \\
\hline 18 & 4 & \\
19 & 2 & \\
20 & 1 & \\
21 & 3 & \\
22 & 2 & \\
24 & 2 & \\
26 & 3 & \\
27 & 1 & \\
28 & 1 & \\
33 & 1 & \\
34 & 1 & \\
39 & 1 & \\
\hline
\end{tabular}

Age of respondents in 1982/1983 varied from 26 to 66 . (The 66 year old was 21 when injured and had 5 children, the last one at age 44 ). Age of injury varied from age 5 to age 39. (5 year old is a C5-C6 quadriplegic; 50 at the time of survey, had 3 children, all by $\mathrm{C}$-section.) 
Birth weight: There were nine babies under 2500 grams (1361 g, 1531 g, 1616 g, 1701 g, 1871 g, 2013 g, 2098 g, 2296 g, 2325 g).

Anaesthesia: Most of these babies were delivered without anaesthesia. Some of the patients who had a Caesarean section had general anaesthesia. Epidural anaesthesia (Watson and Downey, 1980) was used for six deliveries because of hyperreflexia.

Delivery complications were minor except for hyperreflexia. One patient induced with Pitocin, sustained a cerebral intraventricular bleed and coma. There were two patients with prolapsed cord, and one patient with ruptured membranes.

Post partum complications: The dehisence of the episiotomy in two patients is probably significant for spinal cord injured women. Thrombophlebitis and pulmonary emboli should also be considered to be a risk of pregnancy in spinal cord injured women.

The problems related to pregnancy and delivery show a significant number of women with urinary tract infections (Greenland et al., 1984 and Young et al., 1983). This is most likely related to the large number of women who had Foley catheters. Two women had bladder stones, and five had decubitus ulcers.

It is interesting to note that two women found that they had difficulties with their transfers towards the end of their pregnancies because of weight gain.

The treatment of hyperreflexia shows significant variation from epidural anaesthesia (Watson et al., 1980), to general anaesthesia, to the use of drugs, varying from Amyl Nitrate (Spector, 1983) to Magnesium Sulphate and Demerol. This most likely reflects the experience and practice of the physician managing the deliveries. It is noted that only two deliveries were managed by a spinal cord injury specialist. In four deliveries the spinal cord injury specialist was a consultant. The great majority of the deliveries was done by an obstetrician (38); and four by a family practitioner/general practitioner. One delivery was done by the father on the ranch because they just managed to reach the hospital for the previous delivery. They are expecting a third child.

One T4 paraplegic and one T12 paraplegic each had twins.

The congenital abnormality rate was not a special feature in these spinal cord injured women, but the sample is too small for any definite impressions. (Goller and Paeslack, 1980).

Problems of child following delivery: 1 anoxia, 1 Valium withdrawal, 1 possible Valium withdrawal.

It was noted that four women were pregnant at the time of their paralysis and three of them delivered normal babies. (Goller and Paeslack, 1980; Goller and Paeslack, 1972). The fourth patient had an intrauterine death with induction at 20 weeks.

Urinary bladder management varied widely from ileo conduit to intermittent catheterization. Controlled voiding was present in women with a cord lesion below T6. One was an incomplete tetraplegic at C5-6. Many of the controlled voiding women had required a catheter for a short time after delivery.

There were 5 inductions in this group. One was for intrauterine death; two for recurring hyperreflexia; two were done on the due date. In one of these the induction was directly responsible for hyperreflexia and cerebral intraventricular bleed and coma. Only three blood pressures were taken over a 4 hour period. 
(124/80, 140/90, 210/100, prenatal 106/60, 98/60, 110/54, 110/64). (McGregor and Meeuwsen, 1985) (Abouleish, 1980 reported death 2 days post partum due to cerebral haemorrhage as a result of autonomic hyperreflexia.)

Comments by women were: 'Problems with labour and delivery room staff' and 'I knew more than the docs'. One woman reported that she called a nurse from the neighbouring spinal cord injury hospital to come and manage her hyperreflexia. Several of the women felt that they were either over-treated or they were not believed about what they felt was necessary for their care.

One individual was severely over-treated at the time of delivery she had an arterial line, a CVP line, an epidural catheter, an intrauterine catheter, a fetal scalp electrode, and a Foley catheter. She delivered a 2013 grams baby approximately five weeks prior to due date. It was delivered vaginally by outlet forceps, after amniotomy and Oxytocin. The indication for induction was hyperreflexia. Fortunately this patient did not have any iatrogenic complications after her delivery.

\section{Conclusion}

In reviewing the figures, I feel very strongly that those of us who treat spinal cord injured patients should take the initiative to be involved with their pregnancies and deliveries; possibly not actually doing the deliveries but certainly having good communications with the obstetricians so that these patients are managed properly. Autonomic hyperreflexia or dysreflexia, is a severe threat to SCI women with neurological involvement at T6 and above.

I also feel it is essential for the staff of the spinal cord injury centre to be involved in the post partum care in order to teach in particular quadriplegic women the care of their babies in the immediate post partum period. I feel that the additional hospitalisation necessary to accomplish this is certainly worthwhile.

\section{Recommendations}

1. Most spinal cord injured women know their disability well. Listen to the patient, ask questions about skin care, bowel care and bladder care. Review patients independency skills

2. Instruct office staff, and labour and delivery room staffs to be sensitive to the patient's special needs. She is the final authority with regards to her special needs in skin, bowel and bladder care.

3. If the level of paralysis is $\mathrm{T} 6$ and above, the patient will probably have autonomic hyperreflexia or dysreflexia during her contractions whilst in labour. Ask if she has ever had hyperreflexia (this can occur with a full bladder, due to a plugged catheter or a spastic sphincter; it may occur during a bowel programme or indeed from any prominent stimulus below the level of paralysis); and ask her how she manages such a complication. Many spinal cord injury centres give patients printed outlines concerning hyperreflexia.

4. Early labour is common in spinal cord injured women. Weekly checks after 32 weeks are prudent. If dilation occurs, bedrest in the hospital is advised (proper bowel, bladder and skin care is needed). Brethine (Terbutaline) is an effective 
Table 9 Previous pregnancies

4 Women had 1 Previous Pregnancy.

1 Woman had 2 Previous Pregnancies, (1 Miscarriage, 1 Child).

1 Woman had 3 Previous Pregnancies, (2 Miscarriages, 1 Child).

1 Woman had 5 Previous Pregnancies, (3 Children, 2 Miscarriages).

1 Woman had 6 Previous Pregnancies.

Table 10A Prematurity

\begin{tabular}{|c|c|c|}
\hline & Above T6 & Below T6 \\
\hline 3 & 2 wks. & 22 wks. \\
\hline 5 & 4 wks. & 43 wks. \\
\hline 1 & 5 wks. (induced) & 24 wks. \\
\hline 2 & $6 \frac{1}{2} \mathrm{wks}$ & $\begin{array}{l}18 \text { wks. } \\
\text { (Twins, C-section) }\end{array}$ \\
\hline
\end{tabular}

Table 10B Post Maturity

\begin{tabular}{ll}
\hline Above T6 & Below T6 \\
\hline $1 \frac{1}{2}$ wks. & 13 wks. \\
& 1 wks.
\end{tabular}

Table 10C Congenital abnormalities

\begin{tabular}{ll}
\hline $\begin{array}{l}\text { Persistent Ductus Arteriosus } \\
\text { Down's Syndrome }\end{array}$ & 1 \\
1 & $\begin{array}{c}\text { (5th child, mother age } 44 \text { at time of birth, } \\
\text { other } 4 \text { children normal) }\end{array}$
\end{tabular}

Table 11 Death of babies

10 Months, Electrolyte Imbalance Due to G.I. Infection 6 Months, Anoxia, Brain Damage at Birth

1

Table 12 Medications taken during pregnancy

\begin{tabular}{lrlr}
\hline Vitamins & 28 & Daricon & 4 \\
Iron & 25 & Ditropan & 5 \\
Dilantin/Mysoline & 1 & Gantrisin & 6 \\
Dantrium & 1 & Probanthine & 4 \\
Darvon & 1 & Macrodantin & 5 \\
Thyroid & 1 & Antibiotics & 9 \\
Heparin & 1 & (Ampicillin, Keflex, Penicillin, & \\
Monostat & 1 & Nalodixic Acid) & 3 \\
Brethine (Terbutaline) & 1 & Uroqid & 1 \\
Mandelamine & 1 & Gentamycin & 1 \\
Lioresal & 1 & Tobramycin & 1 \\
Valium & 3 & Sulphur & \\
Septra & 2 & &
\end{tabular}

drug to stop or prevent early labour; recently other drugs have been developed.

5. Induction can be difficult in patients with a neurological level of T 6 and above because of the risk of hyperreflexia. In my opinion, induction is contraindicated in these women because of the complications of hyperreflexia, unless the physician and the delivery room staff understand hyperreflexia and are capable of monitoring and managing hyperreflexia. 
Table 13A Bladder management

Ileo Conduit (Daw, 1973)

Controlled Voiding 19 below T6

1 incomplete C5-6

Foley Catheter

Intermittent Catheterization

Suprapubic Catheter

Not Reported

1

20 (8 had catheter short time after delivery)

Table 13B Induction

Pitocin Oxytocin (Tabsh et al., 1982;

Nath et al., 1979)

Laminaria plus Oxytocin

(Ravindran et al., 1981)

Pitocin

1

2 (intraventricular bleed 1 )

Table 13C Professions

\begin{tabular}{lllr}
\hline Ph.D. Psychology & 2 & Engineer & 1 \\
M.D. & 1 & Masters Degree & 2 \\
Cyto-Technologist & 1 & Key Punch Operator & 1 \\
Owner Service Station and Bulk Plant & 1 & Two years college & 1 \\
\hline
\end{tabular}

Table 14A Birth control

\begin{tabular}{llll}
\hline Unknown & 9 & \\
Diaphragm & 1 & \\
Condom & 1 & \\
Foam & 1 & \\
Pills & 4 & \\
Pills-IUD & 3 & \\
Pills-IUD-Foam & 1 & \\
Pills-Condom & 1 & \\
Rhythm & 1 & (T-10, 5 pregnancies) \\
No birth control & 7 & \\
Pregnant at time of paralysis & 4 & \\
Artificial Insemination & 1 & (Twins)
\end{tabular}

Table 14B Birthweight

Variation from 1361 grams to 4848 grams.

( 1 patient delivered 2098 grams baby and also a 4621 grams baby. The babies of T6 and above varied from 1361 grams to 3941 grams)

Table 14C Anaesthesia

\begin{tabular}{lrlr}
\hline General & 12 & No anaesthesia & 31 \\
Epidural & 6 & Pudendal & 1 \\
\hline
\end{tabular}

Table 14D Delivery and postpartum complications

\begin{tabular}{ll}
\hline Bleeding, post C-section & $1(2,000 \mathrm{cc}$, transfusion) \\
Large cervical laceration and bleeding & $1(2,000 \mathrm{cc}$, transfusion) \\
Retained part of placenta plus bleeding & 1 (850 cc, blood loss) \\
Bleeding and infection & 1 \\
Prolapsed cord & 2 \\
Decubitus ulcer & 5 (Greenland and Young, 1984) \\
& (Young et al, 1983) \\
Dehisence of episiotomy & 2 (Oppenheimer, 1971) \\
Thrombophlebitis plus pulmonary emboli & 1 (Oppenheimer, 1971) \\
Peritonitis (post C-section) & 1 (1) \\
UTI & 1 \\
\hline
\end{tabular}


Table 15 Problems in child after delivery

\begin{tabular}{ll}
\hline Anoxia, Brain Damage (one of twins) & 1 \\
Valium withdrawal & 1 \\
Possible Valium withdrawal & 1 \\
\hline
\end{tabular}

6. If the physician accepting the obstetrical care of a spinal cord injured women is not familiar with such patients, a consultation with a spinal cord injury centre physician is recommended.

7. The spinal cord injured woman is disabled but otherwise healthy. She needs proper medical care and close supervision by medical staff alerted to special problems when needed for her and her child.

8. Treat when needed, do not over-treat.

9. Most spinal cord injured women can deliver normal babies vaginally.

10. Always be aware of the threat of decubitus ulcers. Patients need to be turned, padded; especially if on a delivery table for a long time (leg straps could cause problems, especially if the patient is very spastic). The easiest place for delivery of a spinal cord injured woman is in bed.

\section{Résumé}

Grace aux progrès des soins appropriés et l'efficacité de la rééducation, on assiste de plus en plus fréquemment aujourd'hui à des grossesses et des accouchements chex les femmes ayant subi un traumatisme médullaire.

A notre Centre de Rééducation des Traumatismes Médullaires, nous avons eu la chance d'observer deux grossesses chez des femmes tétraplégiques. Les membres de notre équipe sont intervenus pendant la surveillance anté-natale et post-natale et étaient présents pendant l'accouchement. Les problèmes potentiels ont été: menace d'accouchement prématuré (1) hyperreflexia (2) infection urinaire (3) surveillance du traumatisme médullaire (4).

Les menaces d'accouchement prématuré ont été efficacement arrêtées par la Terbutaline. La spasticité a été contrôlée par le Nitrate d'Amyle, l'ARFONAD si nécessaire et, en cas de non contrôle, une césarienne sous anesthésis épidurale était prévue.

Les infections urinaires ont été traitées par les antibiotiques au long cours, tels que l'Ampicilline ou le Kéflex et les vaginites à levures par la Mycostatine.

Une observation a été écrite pour chacune des 2 patientes enceintes.

Le cas $\mathrm{n}^{\circ} 1$ concerne une femme tétraplégique $\left(\mathrm{C}_{5}-\mathrm{C}_{6}\right)$ qui a donné naissance à une fille de 2339 gr avec un score d'apgar à 9-10.

Le cas $\mathrm{n}^{\circ} 2$ concerne une femme présentant une tétraplégie incomplète après résection subtotale d'un épendymome $\mathrm{C}_{2}-\mathrm{C}_{7}$ qui a donné naissance à une fille de $2637 \mathrm{gr}$, avec un score d'apgar à 8-10.

Les deux enfants ont été considérées comme matures avec un âge gestationnel de 38 semaines; elles ont été accouchées par forceps, sans nécessité d'une épisiotomic. Les enfants ont été isolées dans l'unité de nouveau-nés. Les mères ont regagné le centre de rééducation des Traumatismes Médullaires après quelques heures de surveillance en salle de travail.

Suit une revue de la littérature et du courrier: jusqu'a présent, on dénombre 33 observations de femmes d'une pathologie Médullaire ayant accouché d'un total de 50 enfants ( 2 paires de jumeaux, un décès intra-utérin).

21 femmes avaient une atteinte neurologique au niveau de $D_{6}$ et au dessus; elles ont donné naissance à 27 bébés ( 1 paire de jumeaux; une mort in utéro) une hyperreflexia a été observée 22 fois ( 7 césariennes, dont l'après apparition d'une hyperreflexia). 12 femmes avaient une atteinte au dessous de $\mathrm{D}_{6}$ et ont eu 23 enfants (12 césariennes).

\section{Zusammenfassung}

Mit dem Fortschritt von akuter Behandlung und erfolgreicher Rehabilitierung, Schwangerschaft und Entbindung von Rueckgrat verletzten Frauen werden oefters vorkommen. Unser Pflegepersonal an der Rehabilitierungs Abteilung gluecklicherweise hatten zwei gelaehmte schwangere Patienten. Und dieses Personal war beteiligt in der Pflege vor den Geburten und waehrend deren Entbindungen. Probleme wurden festgestellt wie Fruehgeburten, Hyper-reflexia and Urin-System Infektion, Ruckgrat Verleztenversorgung. 
Aktive fruehzeitige Wehen wurden erfolgreich geendet mit einem Praeperat Terbutaline. Hyperreflexia wurde reguliert wenn notwendig mit Amylnitrate, Arfonad, und wenn Hyperreflexia war unkontrollierbar ein Kaiserschnitt konnte ausgefuehrt werden mit epidurale narcose. Urinsystem Infektion wurde behandelt mit langzeitigen Antibiotikum wie Ampicillin oder Keflex und Scheidenhautenzuehdung wurde behandelt mit Mycostatin. An beiden schwangeren Frauen wurder eine Krankengeschichte geschrieben.

Fall No. 1: war eine C5-C6 Tetraplegic und wurde von einem Maedchen entbunden Gewicht von 2339 Gramm mit einen Apgar Einschnitt von 9-10.

Fall No. 2: war eine C2-C7 subtotal Resektion ependymoma Tetraplegic welche von einem 2637

Gramm wiegenden Maedchen entbunden wurde mit einem Apgar Einschnitt von 8-10.

Beide Neugeborene wurden entbunden nach Schwangerschaften von 38 Wochen. Beide neugeborene Kinder wurden mit Geburtenzange ohne Einschnitte entbunden. Die Kinder blieben in entgegengetzter Isolierung in der Neugeborenen Pflege Betreuungs Albteilung. Die Muetter wurden wieder zur Rehabilitierungs Abteilung transportiert nach dem Sie fuer einige Stunden zur Beobachtung in der Entbindungs Abteilungt waren. Ein Ueberblick besteht laufend ueber Schriftstuecke und Literatur. Bis jetzt eine Identifizierung von 33 Rueckgrat verletzten Frauen enthaelt dass von denselben 50 Kinder entbunden wurden. (2 paar Zwillinge und ein Gebaermutter Todesfall). Einundzwanzig Frauen waren Nerven Verletzte T-6 und darueber welche von 27 Kindern entbunden wurden (Ein paar Zwillinge und einen Gebaermutter Todesfall). In 22 von 27 Entbindungen von T-6 in dieser Hoehe und darueber Hyperreflexia war der Fall ( 7 Kaiserschnitte, und ein Hyperreflexia Fall kam vor). Zwoelf Frauen waren unter T-6 welche 23 Neugeborene hatten. (12 Kaiserschnitte waren der Fall).

\section{References}

Abouleish E 1980 Hypertension in a Paraplegic Parturient. Anesthesiology 53(4):348-349.

DAw E 1973 Pregnancy Problems in a Paraplegic Patient with an Ileal Conduit Bladder. Practitioner 211:781-784.

Dickinson, FT 1977 Paraplegia in Pregnancy and Labor: Report of Case and Review of Literature. Journal of the American Osteopathic Association 76:537-539.

Goller H, Paeslack V 1980 Our Experiences About Pregnancy and Delivery of the Paraplegic Women. Paraplegia 8:161-166.

Greenland VC, Young BK 1984 When the Mother is a Paraplegic. Contemporary OB/GYN 24:201-210.

Goller H, Paeslack V 1972 Pregnancy Damage and Birth Complications in the Children of Paraplegic Women. Paraplegia 10:213-217.

McGregor JA, Meeuwsen J 1985 Autonomic Hyperreflexia: A Mortal Danger for Spinal CordDamaged Women in Labor. The American Journal of Obstetrics and Gynecology 151:330-333.

Nath M, Vivian J, Cherny W 1979 Autonomic Hyperreflexia in Pregnancy and Labor: A Case Report. American Journal of Obstetrics and Gynecology 134:390-392.

Oppenheimer W 1971 Pregnancy in Paraplegic Patient: Two Case Reports. American Journal of Obstetrics and Gynecology 110:784-786.

RavindRan RS, Cummins DF, SMith IE 1981 Experience With the Use of Nitroprusside and Subsequent Epidural Analgesia in a Pregnant Quadriplegic Patient. Anesthesia and Analgesia 60(1):61-63.

Rossier A, Ruffieux M, Ziegler W 1970 Faits Cliniques. Gynecologie et Obstetrique 69:537-543.

Rossier A, Ruffieux M, Ziegler W, 1969 Pregnancy and Labour in High Traumatic Spinal Cord Lesions. Paraplegia 7:210-215.

SPECTOR R 1983 Intravenous Nitroglycerin: New Uses for an Old Drug. Journal of Iowa Medical Society 73(3):96.

Tabsh KMA, Brinkman CR, Reff RA 1982 Autonomic Dysreflexia in Pregnancy. Obstetrics and Gynecology 60(1):119-121.

Watson DW, Downey JO 1980 Epidural Anesthesia for Labor and Delivery of Twins of a Paraplegic Mother. Anesthesiology 52(3):259-261.

Young RK, Katz M, Klein SA 1983 Pregnancy After Spinal Cord Injuries: Altered Maternal and Fetal Response to Labor. Obstetrics and Gynecology 62(1):59-63. 